\title{
Identification of Psychological Characteristics of Flat Feet Preschool Children Using Projective Methods
}

\author{
Sultanberk Halmatov ${ }^{1, *}$ \\ ${ }^{1}$ Shool of Health, Ağrı İbrahim Çeçen University, Ağrı, Turkey \\ *Correspondence: Shool of Health, Ağrı İbrahim Çeçen University, Ağrı, Turkey. E-mail: halmatovs@gmail.com
}

Received: January 31, 2019

Accepted: February 27, $2019 \quad$ Online Published: March 12, 2019

doi:10.5430/wje.v9n2p1

URL: https://doi.org/10.5430/wje.v9n2p1

\begin{abstract}
Nowadays, the problem of prevention and correction of various diseases in preschool children has become particularly relevant. This is due, first of all, the presence of a large number of preschoolers $(84.9 \%)$ with different deviations in the state of health and with pathologies in the development of the musculoskeletal system in particular. The problem of studying the psychological characteristics of preschool children with orthopedic diseases seems to be quite relevant, although in contemporary scientific literature this issue has not been adequately reflected. The aim of the research is to identify the psychological characteristics of children of preschool age with a diagnosis of "flat feet" with the help of projective methods. The study was conducted among pupils of preschool educational institutions in Moscow, who are diagnosed with "flat feet" and conditionally healthy children (SWAD, WAD). The average age of the subjects was 6 years. As a result of the research, it has been found that children with a diagnosis of "flat feet", already in preschool age have certain changes in the emotional sphere, especially an increased level of anxiety and fear.
\end{abstract}

Keywords: flat feet, preschool, projective methods, psychological characteristics

\section{Introduction}

Nowadays, the problem of prevention and correction of various diseases in preschool children has become particularly relevant. This is due, first of all, the presence of a large number of preschoolers $(84.9 \%)$ with various deviations in the state of health and with pathologies in the development of the musculoskeletal system in particular (Sterkina \& Korkina, 1997). The problem of studying the psychological characteristics of preschool children with orthopedic diseases seems to be quite relevant, although in contemporary scientific literature this issue has not been adequately reflected.

One of the most common deviations from the norm in the development of the musculoskeletal system is flat feet (Trubnikov, 1994). According to scientists, 40 to $60 \%$ of the world's population suffers from flat feet. Thus, the ideal foot has only less than half of humanity. Studies conducted by Russian scientists in different years revealed flat feet of $20-30 \%$ of the examined children (Galkin, 2017).

In recent years, the percentage of children with disorders of the foot, hip dislocation or other orthopedic problems has increased (Shorin, Mutovkina, \& Tarasova, 1994; Bleiher, 2015). It was found that $67.3 \%$ of preschool children have flat feet. Flat feet of adults are usually the result of underdevelopment or deformation of the child's foot - it is observed in about $50 \%$ of cases.

The question of the pathogenesis of the disease is still actual. According to the researchers, various factors influence the formation of the musculoskeletal system of the child they are the inheritance, ecology, toxicosis during pregnancy, lack of calcium and vitamins, and other causes. Course of childbirth and undetected birth trauma and migrated in childhood viral infections, and much more other also effect on child's musculoskeletal system (Galkin, 2017).

\section{Literature Review}

In order to understand better the nature of the disease, we will analyze some of the anatomical features of the foot. In 
the process of evolution, it has acquired a form that allows us to evenly distribute body weight. The bones of the foot are connected by strong interosseous ligaments (fibrous formations from the connective tissue, presented in the form of a beam connecting the bones) and form its arch, which provides shock absorption of movements when walking and running. Convex arches are oriented in longitudinal and transverse directions. That is why the foot of an adult normally lies on three points - the heel, the head of the 1st metatarsal and 5th metatarsal bone. There are two longitudinal and one transverse arch of the foot. The inner and outer arches form the longitudinal arch of the foot, and the front - transverse. Depending on their deformation there are longitudinal and transverse flat feet (Sapin \& Bilich, 2017).

Some authors consider flat feet as a violation of the functions of the foot, which is externally manifested in the omission of its arches, which is caused by weakening of the muscles and stretching the ligaments of the foot (Dadaeva, Skliarenko, \& Travnikova, 2003). Other authors define flatfeet as the deformity of the foot, reducing the height of the arches in combination with Michaud heel (rotation, wherein the inner edge is lowered, outer raised) and supination (rotation, wherein the outer edge is raised, inner lowered) contracture of the forefoot. As a result, the medial edge of the foot is lowered, its ligamentous apparatus is pathologically stretched, the position of the bones changes; the supinator muscles, which play an important role in maintaining the arch of the foot, weaken and atrophy (Fonarev \& Fonareva, 1983).

Flat feet can be reliably determined only at the age older than 5 years. Weakness of the muscles and ligaments reduces the ability of the foot to depreciation shocks during walking are transmitted to the overlying joints and the spine, and it threatens the development of arthritis, early osteoarthritis, venous insufficiency.

Since the foot is the support, the foundation of the body, therefore it is obvious that the violation of this foundation necessarily affects the formation of the growing organism. When the foot has already been deformed, the ligaments send "signals" to the nervous system about the problem in this "site." In response, the muscles receive an "indication" to join the "struggle" with the deforming forces - that is, to strain. But they are not able to withstand such a load for a long time, therefore they quickly exhausts, relaxes and stretches. A deforming force continues to act on the ligaments. Soon there is a stretching in the ligaments (in particular, if there is an innate pathology of connective tissue), since without the support of muscles they cannot work for a long time. Now the entire load falls on the bones. When the bones are no longer able to withstand, the compressive deformation begins. By this time, the ligaments are finally "disposed" out of order, and the deformation enters a final, irreversible phase. Thus, the change in the shape of the foot not only causes a decrease of its functionality, but, what is especially important, changes the position of the pelvis and the spine. This negatively affects the function of the latter and, therefore, on the posture and overall condition of the child (Galkin, 2017). Inadequate development of the muscles and ligaments of the feet also adversely affects the development of many movements of children, leads to a decrease in motor activity and may become a serious trouble to do many sports (Dadaeva, Skliarenko, \& Travnikova, 2003; Sapin \& Bilich, 2017).

In addition, the gait loses its plasticity, smoothness. In some cases, there is a deformation of the ankle joint (it is also called hallux valgus or X-shaped). Children often complain of fatigue when walking, pain in the ankle or tibia, and often - in the lower back. Some children cannot clearly determine where they are experiencing discomfort or pain, so they do not complain, but simply prefer calm and less active games.

Sometimes deformation of foot can exist for many years (until adulthood) and does not manifest itself. But sooner or later the deterioration will occur, because the body's compensatory abilities are not unlimited (Dadaeva, Skliarenko, \& Travnikova, 2003; Sapin \& Bilich, 2017).

Complications of flat feet can be different. First of all, it is the flattening of the transverse arch of the foot with the subluxation of the first finger outwards in adolescence. If the foot has been in the wrong position for a long time, and especially if valgus deformity of the ankle joint occurs, this can lead to deformation in the joints of the foot and even to a change in the ratio of the articular surfaces of the knee and hip joints. This is accompanied by pain in the legs, especially in the evening hours, and a decrease in depreciation functions leads to pain in the spine. In the future, this can lead to scoliosis, that is, an arc-shaped deformation of the spine to the right or to the left, or to its curvature with the formation of a convex posterior-kyphosis (Yumashev, 2017).

Neglected cases of flat feet often lead to severe health problems and even disability (Trubnikov, 1994). Due to the nature of the disease flat feet creates some restrictions in the choice of profession. Due to the fact that the foot plays an extremely important role in standing, walking, running, jumping, patients with flat feet are not always suitable professions associated with these movements (Galkin, 2017). An example of such professions can be a hairdresser, a salesman, a waiter, a priest, an operative, a military (Dadaeva, Skliarenko, \& Travnikova, 2003). Of course, for such consequences, years of the course of the disease are necessary, so it is necessary to early diagnosis and prevention of 
flat feet.

\subsection{Psychological Features of Preschool Children with Orthopedic Diseases}

Basically, all systems are in a dynamic internal equilibrium, creating a relative constancy of the range of conditions necessary for productive work of the psychic apparatus. Violation of any of the parts or mechanisms of the psychological structure of preschoolers' development, according to Bojovich (2005) can have a decisive impact on the future course of development of the child. According to Bratusya (1988), "the degree of health of the organism is determined by the margin of strength, resistance against harmful effects, that is, how easily and reliably protective forces extinguish, compensate these effects, preventing distortion of the working conditions of the psyche" (Semago, 2001; Sapin \& Bilich, 2017). As for the sick organisms, as Chizhevsky (wrote, they can be considered as systems that are in a state of unstable equilibrium. Here is a small margin of safety (health) in relation to harmful effects, such effects are not extinguished in time, as a result of which the overall instability increases (Sapin \& Bilich, 2017). Defective organs, even if they do not threaten life and generally do not interfere with mental development, in addition to their objective symptoms, cause in the child's soul a sense of inferiority and self-doubt. Rachitic deformities, such as flat feet, X - or O-shaped legs, scoliosis, etc., can affect both the mobility and the self - esteem of the child (Dadaeva, Skliarenko, \& Travnikova, 2003).

Despite the fact that in pre-school age, we can only observe the initial manifestations of the disease, invisible to an outside observer, it seems that this physical deficiency in some way affects the mental development of the child (Shorin, Mutovkina, \& Tarasova, 1994).

This is explained by the fact that under physical stress, a patient with flat feet (even in the early stages of development of the disease) usually feels a number of painful symptoms: pain in the legs, lower back, rapid fatigue, a sharp decrease in performance, and sometimes complete disability (Dadaeva, Skliarenko, \& Travnikova, 2003).

According to a few works authors, in the presence of physical disability due to various diseases, including orthopedic, children have significant personal disorders (Sergeev, 1995; Bleiher, 2015; Dadaeva, Skliarenko, \& Travnikova, 2003). For example, the formation of the patient's personality scoliosis negatively affected by a complex set of psychogenic factors: mental deprivation of the patient (sensory, social, emotional), unfavorable micro environment with constant psychogenic traumatization due to physical disability, and this negative impact is not only in the defect, but also in the painful reaction of others, especially parents (upbringing by type of hyperopic), frequent stay of the child in the sanatorium, a variety of medical interventions. The mental state of the child is largely due to the severity of the motor defect, as a result of which he develops such features as isolation, inactivity, emotional-volitional infantilism, egocentrism. As a rule, these are children with preserved intellect, having possibilities of social contacts and needs for them (Tsokov, 1984; Dadaeva, Skliarenko, \& Travnikova, 2003). The diagnosis of "scoliosis" is set mainly in 12-18 years, i.e. at an age when every individual experiences the crisis of identity formation, during which he tries to understand himself and others. Up to this point, only some orthopedic deviations are recorded, including flat feet of varying severity (Sergeev, 1995; Galkin, 2017; Dadaeva, Skliarenko, \& Travnikova, 2003).

There is not a single innate feature of the body, which would be completely neutral for the mental development of the child. Indeed, even the fact that a child is born beautiful or ugly, physically weak or strong, one way or another affects the formation of his personality. This influence is neither direct nor straightforward. It can lead to completely different (sometimes opposite) results (Adler, 1924; Stolin, 2016).

"Ambition of clumsy children who experience difficulties in movement, all life will always strive to be the first everywhere... A child who has left hope to be nimble, always will be tormented by fear to be late and for any reason will rush and chase, and his whole life will be like on the run" (Adler, 1924). All this cannot only affect the child's self-esteem, but also cause anxiety and, in the future, contribute to the formation of anxiety as a trait.

It would be correct to turn to the theory. First of all, the difference between the terms "anxiety" and "worry" should be clarified. "Anxiety is an individual psychological characteristic that manifests itself in the tendency of a person to frequent and intense experiences of anxiety, as well as in the low threshold of its occurrence" (Romanova \& Potemkin, 1992; Berns, 1986; Panfilova, 2015; Stolin, 2016). In preschool age, the main cause of anxiety, modern researchers call the violation of child-parent relations. Considering this psychological phenomenon as a trait of character, we note that anxiety is an indicator of the problem of personal development and, in turn, has a negative impact on it. "Worry is the experience of emotional discomfort associated with the expectation of trouble, the presentiment of a threatening danger" (Meshcheryakov \& Zinchenko, 2004). In contrast to anxiety, worry is not always seen as negative. Sometimes it is worry that causes the mobilization of human potential. But we should remember that worry can be mobilizing, positively influencing human activity and relaxing, paralyzing (Zakharov, 
2005; Panfilova, 2015). This difference depends on the style of upbringing in childhood.

An increased level of worry can effect on many personal structures, including the level of aspiration. Very low aspiration recorded in people with a clear tendency to avoid failure, which J. Atkinson directly identifies with heightened worry. However, according to him, with expressed anxiety and inadequately inflated aspiration.

Zakharov notes that worry consists of many emotions, one of the components of which is fear.

Some researchers believe that fear is experienced in the vital threat (the integrity and existence of the body, the person as a living being), and worry in the threat of social (personality, needs, etc.). Zakharov interprets the concept of fear as a specific emotion, allocated in a separate category. The emotion of fear is experienced by people at any age. The presence of child's fear is the norm, but if there are a lot of fears, that means a child has an anxiety.

The importance of congenital prerequisites depends, consequently, on what other factors they act in the system and what place they occupy in the functional structures that arise in the child's development. Therefore, it is impossible to determine in advance the impact on the mental development of those or other separately considered the biological background. "No psychological trait is directly biologically determined, but, on the other hand, every psychological feature in the formation of experiencing the indirect impact of innate presuppositions" (Vygotskii, 1986; Bojovich, 2005; Mukhina, 2007; Leontiev, 2016).

Based on all the above-mentioned information, increases the value of the work organization of preventive and corrective focus directly in the conditions of preschool educational institution, where the child is almost every day and where it is possible to ensure the timeliness and regularity of impacts. However, according to Sterkin and Korkina (1997); nowadays, the system of rehabilitation of children in educational institutions is almost not formed. There is a dissociation of the activities of medical and educational personnel in the provision of correctional assistance of children, there is clearly insufficient awareness of teachers and parents in correctional and preventive issues of development, education and training of children. Despite the traditional declaration of the importance of early detection and correction of deficiencies in the child's mental and physical development, correctional and pedagogical activity has not become a priority in the real practice of the education system, although it should be considered as a mandatory part of the state standard of education (Obukhova, 1996; Stolin, 2016).

In the process of organizing the work of preventive and correctional orientation in the conditions of general educational institutions, special attention should be given to the prevention and correction of disorders from musculoskeletal system (defects of posture, flatfoot), since, as mentioned above, among the functional deviations, they have the largest specific gravity (Shorin, Mutovkina, \& Tarasova, 1994).

The peculiarity of this study is that it is not about obvious deformities and diseases of musculoskeletal system which change the appearance of the child. Children with flatfoot disease are perceived by others as healthy, in other words without taking into account physical difficulties. Requirements and expectations from adults and children of the same age may not coincide with abilities of such children.

\subsection{Aim of the Research}

The aim of the research is to identify the psychological charactersits of children of preschool age with a diagnosis of "flat feet" using projective methods. The research of psychological characteristics of children diagnosed with "flat feet" projective methods. The study of psychological characteristics of girls and boys with a diagnosis of "flat feet" projective methods. Preparation of recommendations for educators and parents to correct the identified psychological characteristics of children diagnosed with "flat feet". This research allows us to identify the psychological characteristics of preschoolers with a diagnosis of "flatfeet", which must be taken into account in the correctional work. Timely prevention and correction of attitudes to their success helps to prevent disadaptation of these children in school.

\section{Methodology}

The methods of research were used:

1. Empirical

2. Statistical

The following techniques were used:

1. Anxiety test (worry) (Tammle, Dorki, Amen in modification Panfilova (2015); 
2. Fear research technique Zakharova (modification Panfilova (2015). «Fears in the houses»);

3. Self-esteem research technique «Ladder» (Shur, 1982);

4. Test to determine the level of child's aspirations (Wexler's Mazes);

The choice of research techniques are conditioned by the set tasks.

1. To study the level of anxiety of children, the anxiety test was used (Tammle, Dorki, \& Amen, in modification Panfilova, 2015).

The technique, developed by American psychologists, is a set of 14 plot pictures, each of which the child's face is not traced. Children are encouraged to choose the person in the picture - "merry" or "sad." In this case, the pictures are divided by gender - pictures for girls depict girls, for boys - boys.

Modification Panfilova (2015) is that immediately before testing, the child is diagnosed to recognize emotions by pictograms. In addition, instructions and stimulus material have been changed. In the instructions the child is offered to help the artist choose which face to paint: sad or merry. The change in the stimulus material is that the images of the faces at the bottom of the pictures are removed, since this prevents the preschoolers with the ZPP from making a choice on their own.

The test allows to reveal a situational worry of children, and not personal anxiety, because the answers given by the child depend on their own condition at the time of the examination. It should be borne in mind that children with personal anxiety may require an explanation of the reasons for the lack of an image of the person in the figure. Violations perception of facial expressions will prevent the detection of anxiety, just as some children can make a choice based on the spatial relationship of the depicted figures, rather than analyzing the situation. In connection with these factors, a modification of the test was developed, which consists in the fact that just before the presentation of 14 plot pictures the child is invited to paint a picture with sad and merry faces. This task allows you to identify a violation of the perception of facial expressions.

The survey protocols are subjected to qualitative and quantitative analysis (Panfilova, 2015).

To analyze children's fears, the technique of investigating fears was used. Zakharov, modifications of Panfilova (2015) "Fears in the houses."

This test is designed to diagnose fears of children and adolescents.

Zakharov (2005) proposed age norms of fears and their distribution by sex and age. The test developed by him is easy to use, however, in practice it can cause a number of difficulties related to the fact that children can either deny their fears at all, or on the contrary claim that they are afraid of everything.

In this regard, it has been proposed a modification of the technique of the study of fears Zakharov (2005) in connection with a test of the "Red house - the black house".

Modification Panfilova (2015) is that the technology changes, as well as instructions.

The test is conducted in the form of a survey. The child is invited to settle 29 fears in the red and black houses, and then "lock" the fears in the black house, to calm the actualized fears. Fears in the black house are counted and correlated with age norms (Panfilov, 2015).

3. For research of self-esteem of children as one of factors of formation of level of aspirations the technique "Ladder" Schur (1982) was used.

The methodology developed by Shchur (1982) is intended to reveal the child's system of representations about how he evaluates himself, how, in his opinion, it is assessed by other people and how these representations are correlated (Volchkova \& Fedyaeva, 2012).

The child is offered 6 "ladders" of five steps, where the top step is a positive evaluation, and the bottom one is negative. Then, they are asked to mark their place "among all people" according to the levels, respectively "health", "mind", "character", "happiness", "beauty", "kindness" on each segment. It is believed that the marked values characterize the overall satisfaction - "happiness" and private self-esteem - "health", "mind", "character", "beauty", "kindness."

For preschoolers favorable inflated self-esteem from different positions at all levels (the smartest, most beautiful...). Low self-esteem characterizes the presence of intrapersonal and interpersonal conflicts of the child.

After completing this task, the child is offered to mark his place according to the levels from the point of view of other people mom, dad, educators, children, with a conventional designation (circle, asterisk, cross of another color, etc.). If other 
significant people (according to the child opinion) evaluate him in the same way as he evaluate himself, or give a higher rating - the child is protected psychologically and emotionally well (Panfilova, 2015).

\section{To determine the level of aspiration of children, a subtest of D. Wexler's method "Labyrinths" was used.}

The test consists of 9 labyrinths, one of which is used as a sample, arranged according to the increasing difficulty of the solution. The child is offered to choose the task of any level of difficulty. The goal of the task is to collect as many points as possible. At the same time, the time for solving each task is limited; only the last attempt is not limited, since it is necessary for the child to have a positive impression of participation in the experiment and about the experimenter.

The protocol records the statements of the child accompanying the decision of tasks, the number of the attempts are also recorded the level of complexity, the dynamics of choice, the reaction to success and failure. Data is depicted in a graph.

Qualitative analysis allows us to conclude about the level of claims of the child.

\subsection{Sampling}

The study was conducted among pupils of preschool educational institutions in Moscow, who are diagnosed "flat feet" and with conditionally healthy children (SWAD, WAD). The average age of the subjects is 6 years.

To solve the tasks, the experimental and control groups of children were examined.

The experimental group consisted of 35 children diagnosed with "flat feet", 20 boys and 15 girls.

The control group consisted of 26 children, without diagnosed orthopedic disorders 13 boys and 13 girls.

\section{Results}

To describe the obtained results, along with qualitative analysis of the data obtained at all stages of the study, statistical processing of data was carried out using the STATISTICA 6 for Windows application software package.

Description of the results of the self-assessment study.

Table 1. Results of the "Ladder" Method

\begin{tabular}{lllllllll}
\hline Test subjects & \multicolumn{3}{c}{ General self-assessment } & \multicolumn{4}{c}{ Social self-assessment } \\
\cline { 2 - 8 } & Low Medium low & Medium & High & Low & Medium low & Medium & High \\
\hline Exp.gr.b & - & 5 & 5 & 90 & - & - & 15 & 85 \\
Cont.gr.b & - & 8 & 8 & 84 & - & 8 & 38 & 54 \\
Exp.gr.g & - & - & 13 & 87 & - & - & 7 & 93 \\
Cont.gr.g & - & - & - & 100 & - & - & 15 & 85 \\
\hline
\end{tabular}

Data are given in \% (Exp.gr.b. - experimental group of boys, Cont.gr.b. - control group of boys, Exp.gr.g. experimental group of girls, Con.gr.g. - control group of girls).

Speaking about the ratio of the levels of overall self-assessment (Fig. 1), we can observe its high level in both groups.

If we compare the results in Table 1, which shows data for boys and girls separately, it can be noted that in the control group of girls, a high self- assessment is observed in $100 \%$ of cases. Girls of the experimental group do not have medium low self-assessment, then in boys of both groups this indicator is present and makes up $5 \%$ in the experimental group; in the control group $8 \%$ (the difference is not statistically significant). 


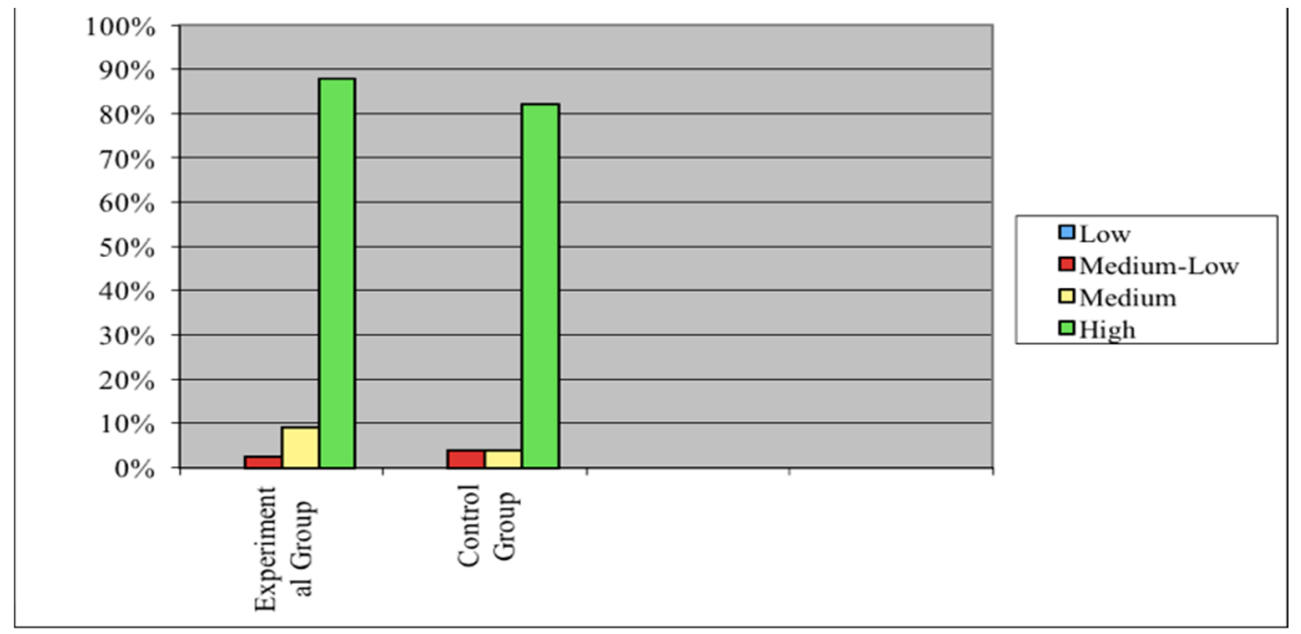

Figure 1. The Ratio of the Levels of general Self-Assessment According to the Method of "Ladder"

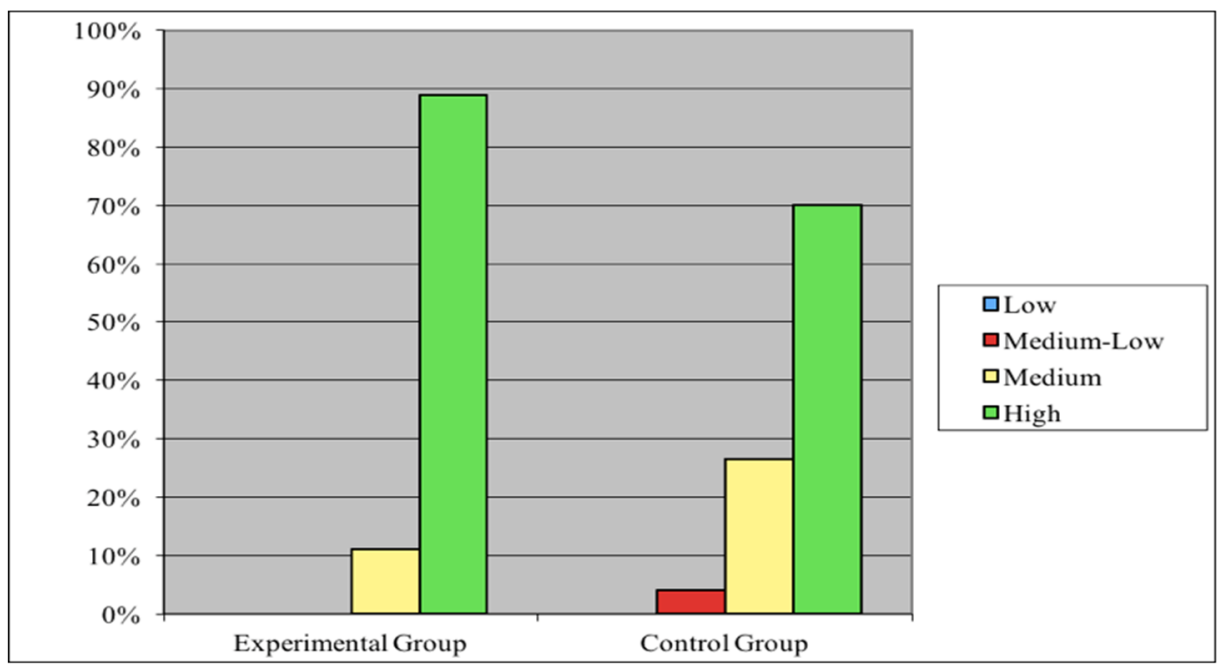

Figure 2. The Ratio of the Levels of Social Self-Assessment by the Method of "Ladder"

Comparing indicators of social self-assessment, we see (Fig.2) that in the experimental group the percentage of children with a high level is much higher than in the control group. There is also a medium low level of social self-assessment, while in the experimental group there are no such children.

If we look at the results of girls and boys separately (Table No. 1), the following picture is observed for social self-assessment: in the experimental group, a higher percentage was recorded in a larger percentage of boys (85\%), in the control group this percentage is much lower and is only $54 \%$ (the difference is significant at the level of $\mathrm{p} \leq 0.01$ by the Fisher criterion). The medium level of self-assessment was shown by $15 \%$ of the children in the experimental group, which is almost twice as high as in the control group boys (8\%) (the difference is significant at the level of $\mathrm{p} \leq 0.01$ by the Fisher criterion). The medium low level of self-assessment is not observed for the boys of the experimental group, and boys of the control group it reaches $38 \%$ (the difference is significant at the level of $\mathrm{p} \leq 0,001$ by the Fisher criterion).

Girls of the experimental group, the percentage of high social self-assessment (93\%) is higher than in control group of girls $(83 \%)$ (the difference is not statistically significant). Low and medium low self-assessment in both groups is not observed.

Description of the results of the research of the level of aspiration shown at Table 2. 
Table 2. The Results of the Test to Determine the Level of Aspiration. (Data are given in \%.)

\begin{tabular}{lllll}
\hline Test subjects & \multicolumn{3}{c}{ Level of aspiration } \\
\cline { 2 - 5 } & Low inadequate & Low adequate & High inadequate & High adequate \\
\hline Experimental group of boys & 25 & 33 & 17 & 25 \\
Control group of boys & 57 & - & 29 & 14 \\
Experimental group of girls & 14 & 43 & 43 & - \\
Control group of girls & 20 & 40 & 20 & 20 \\
\hline
\end{tabular}

Speaking about the ratio of the levels of aspiration (Fig. 3) in the groups of subjects, it should be noted that in both groups the low level of aspiration prevails. It is interesting that in the experimental group, it is a low adequate level, and in the control group - it is low inadequate. Children with a high level of aspiration (both adequate and inadequate), as can be seen from Fig. 3, in the experimental group are greater than in the control group.

As can be seen from Table 3, the largest indicators of an inadequate low level of aspiration are in the control group of boys (57\%), while in all other groups it is $25 \%, 14 \%$ and $20 \%$.

Healthy boys do not have a low adequate level of aspiration; whereas in the experimental group it is $33 \%$ (the difference is significant at the level of $\mathrm{p} \leq 0.01$ by the Fisher criterion). Boys of the control group do not even try to solve a more complicated problem.

The results of the research of the level of aspiration of boys show that there is no significant difference between the groups in terms of high levels of aspiration, but there is a significant difference between adequate and inadequate. In the experimental group, the indices of a high adequate level of aspiration are greater than in the control group (25\% and $14 \%$, respectively) (the difference is significant at the level of $\mathrm{p} \leq 0.001$ by the Fisher criterion).

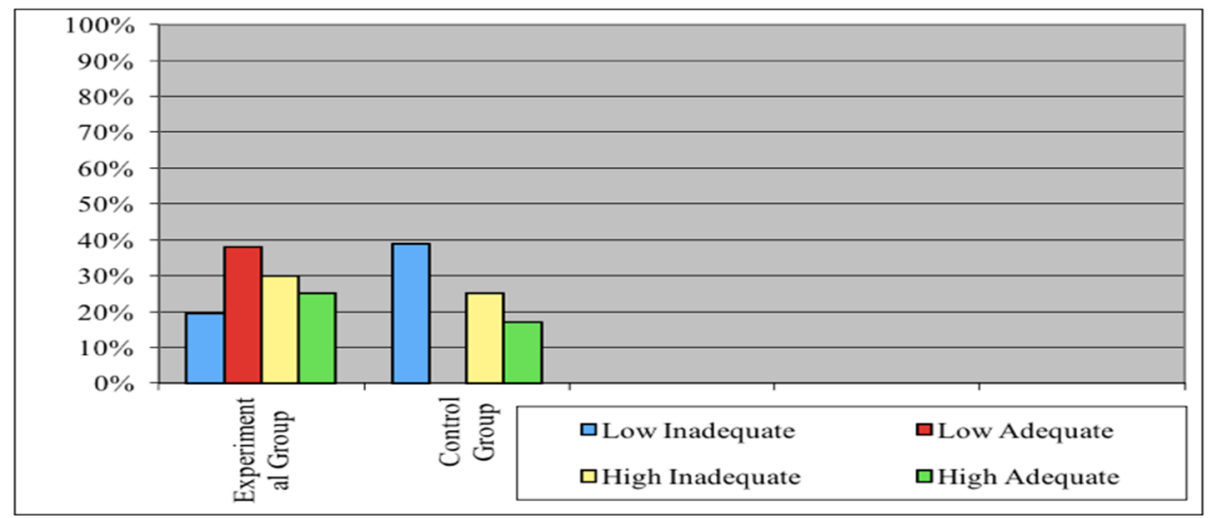

Figure 3. Ratio of Different Levels of Aspiration

The results of studies of the level of aspiration of girls in the parameter "high level of aspiration" (if not divided it into inadequate and adequate) showed no significant difference. If we consider these levels separately, it can be noted that in the experimental group there is no adequately high level at all, and in the control group the data were divided exactly in half (by 20\%). Thus, it turns out that the girls of the experimental group set for themselves higher tasks than the girls of the control group and try to fulfill them (even despite the failures).

Comparing the results of the methodology of the research of the level of aspiration and social self-assessment (in the experimental group the percentage of high self-assessment is greater), it can be assumed that these girls are more independent from the assessment of others.

Description of the results of the research of the level of anxiety and fears shown at Table 3. 
Table 3. Results of the Methods "Anxiety test" and "Fears in the houses". (Data are given in \%.)

\begin{tabular}{lllllll}
\hline Test subjects & \multicolumn{3}{c}{ Level of anxiety } & \multicolumn{3}{c}{ Fears } \\
\cline { 2 - 7 } & Low & Medium & High & Low & Medium & High \\
\hline Experimental group of boys & 27 & 60 & 13 & 7 & 60 & 33 \\
Control group of boys & 18 & 82 & - & 10 & 70 & 20 \\
Experimental group of girls & 15 & 85 & - & - & 73 & 27 \\
Control group of girls & 17 & 83 & - & 18 & 37 & 45 \\
\hline
\end{tabular}

In the experimental and control groups, a larger percentage of children showed a medium anxiety level (Fig. 4). In the experimental group there is a small percentage of preschool children with a high level of anxiety, in the control group the high level was not detected (the difference is significant at the level of $p \leq 0,001$ according to the Fisher criterion).

According to the data in Table 3. a high level of anxiety in the experimental group was shown only by boys (13\%). However, this factor does not allow us to speak of high anxiety as a character trait of these boys, since this method measures only situational anxiety. In none of the groups of girls a high level is observed.

According to the results of the "Fears in houses" technique, we have the following data: the predominant percentage of children experience the average number of fears (Fig. 5). In the control group of children, the percentage is higher and with a low number of fears (the difference is significant at $\mathrm{p} \leq 0.001$ according to the Fisher criterion) and with a high (although the latter criterion is not significant). A high number of fears in the experimental group of boys are experienced by $13 \%$ more children (table 3 ) than in the control group $(20 \%)$.

If we compare two groups of girls, it shows that in the experimental group the percentage of children with a high number of fears is significantly lower (27\%) than in the control group of girls (45\%) (Table No. 3). The last indicator is the highest in this method among all groups of children: boys and girls. A low number of fears in the experimental group of girls are absent, while in the control group this figure is $18 \%$ of children.

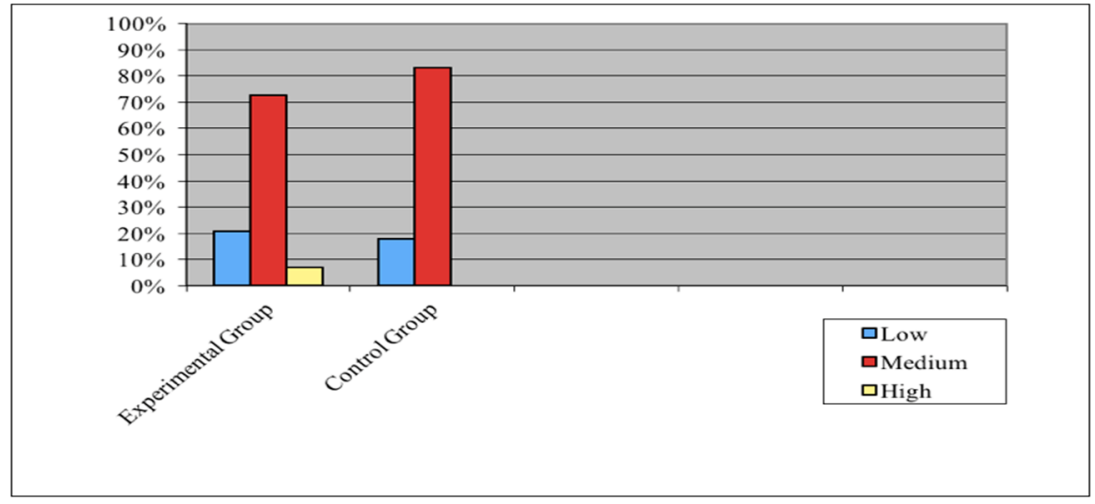

Figure 4. The Ratio of Different Levels of Anxiety

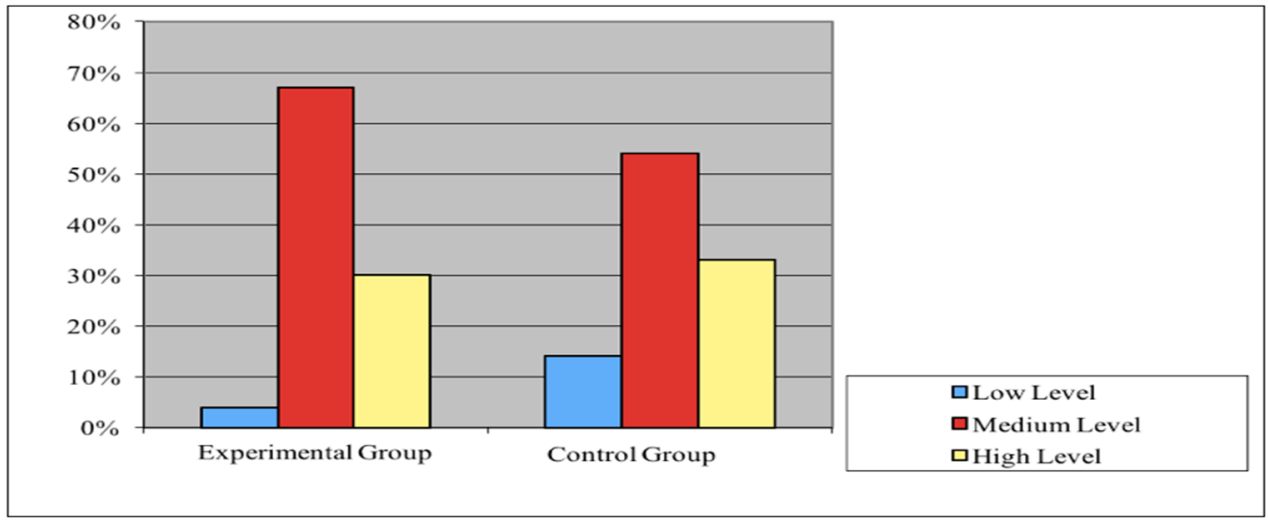

Figure 5. The Ratio of the Number of Fears by the Method of "Fears in houses" 


\section{Discussion}

In this research, we investigated the psychological characteristics of children diagnosed with "flat feet", especially the indicators of self-assessment, level of aspiration, anxiety and fear. Since these diseases can be reliably determined only at the age of older than 5 years, so the experiment involved children of preschool age.

The experiment involved children brought up in children's institutions in specialized groups of orthopedic profile, so this psychological feature, which is noted in the theoretical studies on this issue, such as low self-assessment was absent due to the specially created psychological and pedagogical conditions.

Some studies reported that children with posture disorder had difficulties in adapting to social environments (Dadaeva, Skliarenko, \& Travnikova, 2003; İsaeva, 2015). Of all the children who participated in the study conducted by Volkov (2008), 54,4\% were found to have psychological weakness, which was also reported to lead to psychopathological problems in the long term. Majority of children with posture problems have high anxiety levels. These children were reported to have significantly low self-confidence. A study conducted with adolescents who had flatfoot problem reported that $77,8 \%$ of the participating individuals had high anxiety levels.

As a result of the research, it has been found that children with the diagnosis of "flat feet" already in the preschool age have certain changes in the emotional sphere, namely, an increased level of anxiety and fears.

The recommendations offered to teachers and parents will help to correct these children's problems before entering school.

Conducted research of children diagnosed with "flat feet", showed that they have a high level of self-assessment, which is certainly the merit of the specialized agencies in which the experiment was conducted. However, their level of anxiety and fears is higher than that of healthy children. Analyzing the results of the study, we can draw the following conclusions.

\section{Conclusions}

The experimental study partially proved the hypothesis that preschool children diagnosed with "flat feet" have certain psychological characteristics (anxiety, fears), which are compensated by specially created psychological and pedagogical conditions.

The majority of children involved in the experiment have high level of self-assessment, which corresponds to the age characteristics and indicates the emotional and psychological well-being of the child.

In experimental groups, the percentage of children with a high level of social self-assessment is higher than in control groups, which confirms the importance of the social factor for this age.

Children from the experimental and control groups have a low level of aspiration, which is determined by the social conditions of the present time.

The children of the experimental group showed a high level of fear and anxiety, while the children of the control group do not have it.

\subsection{Recommendations}

Correctional work with children with increased anxiety can be carried out in several directions: the development of the ability to express their emotions, to teach the child ways of muscle and emotional tension and to practice skills of self-possession in situations that injure the child.

The work can be carried out simultaneously in several directions, or, depending on the priority chosen by adults, gradually and consistently.

Based on the above, some specific recommendations were made:

- As often as possible to call the child by name and praise him in the presence of other children and adults. For this purpose, it is possible to make in groups so-called "stands of achievements": ("Our achievements", "I made it", "We can", and others), and also to award children with any diplomas, tokens or stickers.

- Children can also be encouraged to do something that is quite prestigious in the group.

- It is very desirable to avoid the comparison of children with others. If the teacher wants to make any comparison, it is better to compare today's results with the results of the child yesterday or a week ago.

- When giving an assignment to such a child, it is best to try to establish eye contact with him, do not rush him with 
an answer, and try not to repeat the task several times, because every new treatment he will perceive as a new stimulus.

- To ensure that such a child does not consider himself to be worse than others, it is preferable in the group to conduct conversations with children, during which children discuss the difficulties experienced by them in various situations (the educator can ask the topic of a conversation). Such conversations are useful not only for anxious, but also aggressive, hyperactive children.

\section{References}

Adler, A. (2002). Praktika i teoria individualnii psihologii. Moskva: İzdatelstvo Psihoterapii. (Практика и теория индивидуальной психологии. - М.: Изд-во института Психотерапии)

Barutus, B. (1988). Anomalii lichnosti. Moskva: İzdatelstvo "Misl".

Berns, R. (1986). Development of the "I-concept" and education (pp. 230-256). Moskova: Progress. ( Бернс P. «Развитие «Я-концепции» и воспитание». М.: Прогресс, 2002.)

Bleiher, V. (2002). Prakticheskaia patopsihologia. Rukovodtsvo dla vrachei I med. rabotnikov (pp. 230-246). Rostov na Donu: Feniks. (Блейхер В. М. (2015). Практическая патопсихология. Руководство для врачей и мед. работников. - Ростов-на-Дону: Феникс)

Bojovich, L. (2005). İzbrannie psihologicheskie trudi. Moskva: Mejdunarodnaia pedagogicheskaia akademia. (Божович Л.И. (2005). Избранные психологические труды. - М.: Международная педагогическая академия)

Chizhevsky. A. (1959). Rukovodstvo po primeneniyu ionizirovannogo vozduha v promishlennosti, selskom hoziastvie $i$ meditsine (pp. 21). Moskow: Gosplanizdat.

Dadaeva, O., Skliarenko, R., \& Travnikova, N. (2003). Clinical and psychological characteristics of children and adolescents with scoliosis. 3, (pp. 10-14). St. Petersburg. Medico-social expertise and rehabilitation. (Дадаева О.А., Скляренко Р.Т., Травникова Н.Г. (2003). Клинико-психологические особенности детей и подростков больных сколиозом. - М.: Медико-социальная экспертиза и реабилитация.)

Fonarev, M., \& Fonareva, T. (1983). Ortopedicheskie bolezni. Spravochnik po detskoi lechebnoi fizkulture (pp. 319-321). Leningrad: Metidsina. (Фонарев М.И., Фонарева Т.А. (1983). Ортопедические болезни. Справочник по детской лечебной физкультуре. Под ред. М.И. Фонарева. - Л.: Медицина,)

Galkin, U. (2017). Profilaktika ploskostopia (pp.45-68). Smolensk: SGFK. (Галкин Ю.П. (2017). Профилактика плоскостопия. - Смоленск: СГИФК)

İsaeva, O. (2015). Differentiated approaches to the recovery of 16-17-year-old students with impaired posture in the process of physical education. Ivanovo: Ivanovo State Medical Academy.

Leontiev, A. N. (2004). Deiatelnost. Soznaniye. Lichnost: uchebnoe posobie. Moskva. Smsl: Akadeia. (Леонтьев А.Н. (2016). Деятельность. Сознание. Личность. Учебное пособие. - М.: Академия.)

Meshcheryakov, V., \& Zinchenko, V. (2004). Bolshoi psihologicheskii slovar (pp.666). Moskva: Olma-Press. (Мещеряков Б.Г, Зинченко В.П.(2004). Большой психологический словарь. - М.: Олма-Пресс,- 666 с)

Mukhina, V. S. (2007). Vozrastnaia psihalogia. Uchebnik dla studentov vissheii uchebnii zavedenii (pp. 230-268). Moskva: İzdatelskii tesntr. Akademia.( Мухина В.С.(2007). Возрастная психология. М.: Академия)

Obukhova, L. F. (1996). Children's (age) psychology: textbook. M.: Rus. ped. agency, 374.( Обухова Л. Ф.(1996). Детская (возрастная) психология. Учебник. - М.: Российское педагогическое агентство)

Panfilova, M. (2015). Game therapy of communication. Tests and correctional games (pp. 122-128). M.: İzdatelstvo Gnom i D.( Панфилова M.A. (2015). Игротерапия общения. Тесты и коррекционные игры. - М.: Изд-во Гном и Д.)

Romanova, E. S., \& Potemkina, S. F. (1992). Graphical methods in psychological diagnosis (pp. 86-114). Didactic, Moscow.( Романова Е.С., Потемкин О.Ф.(1992). Графические методы в психологической диагностике.)

Sapin, M. R., \& Bilich, G. L. (2017). Human anatomy. Textbook for students 96-135). M.: Visshaia shkola. (Сапин М.Р., Билич Г.Л. (2017). Анатомия человека. Учебник для студентов биол. спец. вузов. - М.: Высшая школа.) 
Semago, M. M. (2001). Psychological, medical and pedagogical examination of the child (pp. 22-53).Moskva. (Семаго М.М. (2001). Психолого-медико-педагогическое обследование ребенка.)

Sergeev I. (1995). Prevention of flatfoot, 6, (pp. 58-60). Doshkolnie Vospitanie, (Сергеев И. (1995). Профилактика плоскостопия. - М.: Дошкольное воспитание. № 6, с. 58-60.)

Shorin, G., Mutovkina, T., \& Tarasova, T. (1994). Ways to improve health work in preschool institutions. Chelyabinsk. (Шорин Г.А., Мутовкина Т. Г., Тарасова Т. А. (1994). Пути совершенствования оздоровительной работы в детских дошкольных учреждениях. Проблемы оптимизации учебно-воспитательного процесса в ИФК: Матер. научн.-метод. конф. - Челябинск: ЧГИФК.)

Shur, V. (1982). Methodology for studying the child's ideas about the relationships of other people to him. Psychology of personality: theory and experiment. Mocow. (Щур В.Г. (1982). Методика изучения представлений ребенка об отношениях к нему других людей. Психология личности: теория и эксперимент. М.)

Sterkina, P., \& Korkina, Yu. (1997). Results of the first meeting of the Scientific and Methodological Council on Correctional and Pedagogical Problems of Preschool Education, 10, (pp. 2-5). Doshkolnie Vospitanie. (Стеркина Р.Б., Коркина Ю.В. (1997). Итоги первого заседания Научно-методического совета по коррекционно-педагогическим проблемам дошкольного образования МОПО РФ. - М.: Дошкольное воспитание, № 10, с. 2-5.)

Stolin, V. V. (2016). Self-consciousness of personality. M.: İzdatelstvo MGU. (Столин В.В. (2016). Самосознание личности. - М.: Изд-во МГУ, 2006.)

Trubnikov, V. (1994). Diseases and damage to the ODA (pp. 188-195). Kiev: Zdarovia. (Трубников В.Ф. (1994). Заболевания и повреждения ОДА. - Киев.: Здоровя)

Tsokov, В. (1984). The relationship between self and the level of anxiety (pp. 12-19). Sofya: Psihologia, №1. (Цоков Б. (1984). Взаимосвязь между Я образом и уровнем тревожности. - София: Психология, №1.)

Volchkova, N. I., \& Fedyaeva, M. V. (2012). İsledovanie urovnia agresivnosti u sovremennih podrostkov. Elektronni nauchno-prakticheski jurnal "Psihalogia, sotsialogia I pedagogika", 6, 778.

Volkov, A. (2008). Medical and psychological characteristics of violations of posture in children and teenagers. The dissertation of the candidate of medical sciences. Moscow.

Vygotskii, L. (1986). Sobranie soch. M. Pedagogika. (Выготский Л.С.(1986). Собр. соч.: В 6 т. Т. 6. М.: Педагогика)

Yumashev G. S. (2017). Traumatology and orthopedics. М.: Medicine.( Юмашев Г.С.(2017). Травматология и ортопедия. - М.: Медицина.)

Zakharov, A. (2005). Day and night fears in children (pp. 48-69). Sp: Rech. (Захаров А.И. (2005). Дневные и ночные страхи у детей. - Спб.: Речь). 